\title{
"Biorationals" in integrated pest management strategies
}

\author{
Ewa Matyjaszczyk ${ }^{1}$ (1)
}

Received: 29 June 2018 / Accepted: 26 July 2018/Published online: 10 August 2018

(C) The Author(s) 2018

\begin{abstract}
Preference of non-chemical methods over chemical methods if they provide satisfactory pest control is one of the rules of integrated pest management, which is obligatory in the European Union since 2014. Professional users of pesticides are encouraged to switch to practices and products with the lowest risk to human health. Products of biological origin that may have positive impact on plant health are very varied with regard to origin, composition and mode of action as well as very inhomogeneous in terms of their legal status and the paths of market placement. The paper explains in what way they may be used in the integrated pest management strategies.
\end{abstract}

Keywords Integrated pest management $\cdot$ Biological $\cdot$ Plant protection $\cdot$ Biostimulants $\cdot$ Low risk $\cdot$ Basic substances

\section{Introduction}

The paper presents the content of the lecture delivered during the 8th International Symposium "Plant Protection and Plant Health in Europe" on the topic "Efficacy and risks of "biorationals". The Symposium, held in Braunschweig on 13th and 14th of December 2017, was jointly organised by Deutsche Phytomedizinische Gesellschaft, Julius Kühn-Institut and Humboldt University, Berlin.

The term "biorationals" had been used in the title of the symposium as an operative expression to speak about certain kinds of components in plant protection strategies, which on the one hand are assumed to have advantages in regard to risk characteristics while at the same time provide acceptable efficacy in reducing pest impact. The products are often biologically derived; however, if synthetic, they are structurally similar and functionally identical to a biologically occurring material. This includes micro-organisms, plant extracts, basic substances, as well as nonpesticidal products like biostimulants, biological yield enhancers, plant health promoters, and soil conditioners. Some of them may not reveal sufficient efficacy against pests when alone, but may be useful when integrated into

Ewa Matyjaszczyk

e.matyjaszczyk@iorpib.poznan.pl

1 Plant Protection Institute - National Research Institute, Ul. Władysława Węgorka 20, 60-318 Poznan, Poland wider plant protection strategies (Feldmann 2018). Many of them can be used in organic agriculture (Matyjaszczyk 2018).

Without insisting on use of the term "biorationals", it is worth stressing that products from the group described above may have positive impact on plant health and are very varied from the point of view of origin, composition and mode of action as well as very inhomogeneous as regards their legal status and the paths of market placement. Their use in plant production is also very different: some work directly against pests and are highly selective and their efficacy is on the equal level to that of chemical plant protection products (Bereś 2016), while some others work mostly on crop plants increasing their resistance against a number of factors, both biotic and abiotic. The efficacy of the latter group with regard to pests and diseases, and in particular every single harmful organism, is often inconsiderable.

The aim of the paper is to present the ways in which different types of biological or biologically derived products fit into integrated pest management (IPM) rules and how they can be useful in plant production, decreasing the dependency on chemical control. 


\section{Legal provisions regarding integrated pest management}

The rules of integrated pest management are compulsory and must be observed by all professional users of plant protection products in the European Union (EU) since January 2014. Two legal acts in parallel enforced the obligatory integrated pest management in the EU: Regulation 1107/2009 concerning the placing of plant protection products on the market and repealing Council Directives 79/117/EEC and 91/414/EEC as well as Directive 2009/ 128/EC establishing a framework for Community action to achieve the sustainable use of pesticides. Directive 2009/ 128/EC also sets out the definition and the general principles of integrated pest management that are legally binding in the EU.

According to the definition given by the aforementioned Directive, "integrated pest management" means careful consideration of all available plant protection methods and integration of measures that discourage the development of harmful organisms, keep the use of plant protection products and other forms of intervention to levels that are economically and ecologically justified and reduce or minimise risks to human health and the environment.

Also Directive 2009/128/EC stresses that its aim is to reduce the impacts of pesticide use on the environment and promote the use of integrated pest management and of alternative approaches or techniques such as non-chemical alternatives to pesticides.

\section{How "biorationals" fit into integrated pest management rules?}

The principles of IPM that are legally binding in the EU are listed in Annex III of the Directive 2009/128/EC, and their full version can be easily accessed online (https://eur-lex. europa.eu/LexUriServ/LexUriServ.do?uri=OJ:L:2009:309: 0071:0086:en:PDF). Below, the abbreviated version is given for practical purposes, quoted after Matyjaszczyk (2015a). It seems that at least some of biological and biologically identical products discussed in this paper may be useful in the implementation of those principles, which are underlined below. Each of the underlined principles is discussed in detail.

1. Prevention and/or suppression of harmful organisms. The first rule of IPM is prevention and suppression of harmful organisms development. Preventive methods such as crop rotation, adequate cultivation techniques, making use of resistant cultivars and healthy planting material, balanced fertilisation, preventing the spreading of harmful organisms and preservation of biodiversity are used in agriculture for hundreds of years (Bak and Gaj 2016; Tratwal and Bocianowski 2018).

A number of microbial as well as other nonpesticidal products of biological origin are promoted by their manufacturers as preventive measures of pest control. It is debatable if this is really in line with the intention of the legislator of Directive 129/2009. However, it is a fact that some of them may have positive impact on the crop health when applied preventively. This effect may be obtained in different ways. Some products from this group may suppress pest development, some stimulate crop defence system, and other by improving the conditions of plant growth or availability of nutrients allow the crop to grow better and be more robust to pest pressure (Yakhin et al. 2017; Kocira et al. 2018; Przybysz et al. 2014; Kazda et al. 2015; Ghorbanpour et al. 2018; Danilčenko et al. 2017).

It seems that from the point of view of current EU law, the preventive effect is the only one that can be legally claimed for those biostimulants that are not placed on the market as plant protection products. Regulation 1107/2009 explicitly defines that, regardless of the composition, all products acting against harmful organisms are plant protection products and should be registered as such. Also the preparations influencing the life processes of plants, other than as a nutrient, fall into plant protection product definition. For biostimulant producers, it means that even claims regarding plant strengthening properties of biostimulants should be formulated with due consideration to the wording of Regulation 1107/2009, unless they want the biostimulant to be registered and marketed as plant protection product.

2. Monitoring of harmful organisms.

3. Application of protection measures on the basis of the monitoring of harmful organisms and threshold levels

Based on the results of the monitoring, the professional user has to decide whether and when to apply plant protection measures. If the application is necessary, then the most suitable product is chosen. The choice of product should be based on the pest pressure. Some biological plant protection products have lower efficacy than chemical ones. However, moderate effectiveness in some cases is sufficient to keep the pest on the acceptable level.

Recently the guideline EPPO PP 1/296 (1) for the specialists performing efficacy assessment for the registration of plant protection products has been published by European and Mediterranean Plant Protection Organisation (EPPO 2017). It provides a 
framework for the minimum efficacy data requirements needed to demonstrate that a low-risk plant protection product is sufficiently effective and crop safe for authorisation. It also comments on efficacy, stressing that moderate effectiveness of the low-risk product may be acceptable.

4. Preference of non-chemical methods over chemical methods if they provide satisfactory pest control.

This rule seems a straightforward encouragement for use of the group of products described in this paper. In cases when biological and chemical plant protection products are registered for the same scope of use and show similar efficacy, biological products should be chosen in IPM rather than chemical.

When applying this rule, attention should be paid also on the cost and the farmers' knowledge. Firstly to apply non-chemical methods, the farmers must be aware that such methods are available. To make use of them, they must be convinced that they are also costeffective. Chemical companies organise numerous trainings for farmers and advisors to educate them on how to use new pesticides and to remind them about the known ones. In case of biological methods, awareness must be raised regarding their existence. In addition, farmers need to be taught on how to use them and that they are efficient and cost-effective. The proper application of microbial and biological products is often more challenging than that of a chemical product, but at the same time often even more important to ensure effectiveness. Factors such as temperature, humidity, soil and leaf moisture, both plant and pest growth stage, edaphic conditions must be often considered to obtain optimal efficacy, in particular in the case of micro-organisms.

5. Preference of specific pesticides and of pesticides with the least side effects over the others.

This IPM rule is in fact very strong encouragement for use biological and microbial plant protection products. Pesticides based on substances produced by microbes (such as spinosad) as well as the micro-organisms registered as plant protection products are usually very specific. "Specific" means that they affect only very narrow group of pests and do not affect other groups of organisms, neither other pests nor beneficials.

The micro-organisms and biological substances are not devoid of side effect (Deising 2018), but those registered as plant protection product are really well studied and their safety and lack of unwanted side effects are ensured by the registration process. Also they usually decompose easily and are less persistent than chemical pesticides (OECD 2008; Koch et al. 2018).
6. Keeping the use of pesticides to levels that are necessary.

7. Prevention of resistance development.

Where the level of harmful organisms requires repeated application of pesticides to the crop, the available anti-resistant strategies should be availed. Plant protection products of biological origin and micro-organisms usually have different properties and modes of action than chemicals (FRAC 2018; IRAC 2018). Their interchangeable use with chemical pesticides may therefore bring good results in the resistance prevention strategies.

However, it is also important to stress that microbial and biological plant protection products themselves are not free from risk of resistance development (Amorim et al. 2010; Crespo et al. 2011; Boyer et al. 2012). Constantly repeated application of the same microbial product or plant extract is therefore not in line with this IPM measure.

8. Checking protection results.

\section{Misunderstandings regarding the use of biological products in the light of IPM rules}

The fact that the group of products discussed in this paper fits excellent into IPM strategies should be stressed. However, not only the use of plant protection products, but also all other forms of intervention should be justified.

Therefore in the light of IPM rules, use of any product in agriculture, no matter if chemical or biological, should be well thought out. Certainly, no products should be used without reason. Even, biological products may be in some cases a burden for the crop and bacteria may produce substances that are dangerous for humans (Deising et al. 2017; Zitko et al. 1991). Even if a product is as safe for the environment as clean water, its application still needs a number of runs of the agricultural machinery on the farm and, therefore, causes the correlative mechanical crop damages and soil compaction as well as the use of fuel (Matyjaszczyk 2017).

It is important to bring attention to the need of moderation, as it seems that obligatory IPM is used in a marketing strategy of numerous producers of different preparations. There is clear benefit from using some of them. However, if the only or the main argument for using certain product is that the product is safe for environment, it seems that such an argument is not robust enough.

Moreover, in case of at least some of the products promoted as "biological" or "environmentally friendly" the composition and mode of action are unknown; 
therefore, it is not quite sure that they are really safe and effective. Some of them may have been never registered, as there is a loophole in the law on market placement of some products used in agriculture in at least several EU Member States (Traon et al. 2014). Therefore, at least in some of EU Member States neither safety nor efficacy of a number of products sold and promoted for use in agriculture is confirmed (Matyjaszczyk 2015b). Facing lack of any kind of barrier for their market placement, the number of marketed products has a potential of quick growth. IPM and the fact that they are "biological" are plausible arguments and well sounding catchwords, used for their marketing campaigns. However, based on the definition of IPM, such argumentation is inherently erroneous. To be recommended in IPM, a product should be not only safe but also effective and useful in the particular case of its application.

Besides, it is worth stressing that:

1. Claims like "Product $X$ should be used in IPM strategies" are a misuse. According to the rules of IPM, there is no necessity of using any commercial products in agriculture.

2. Promotion of a fertiliser or an unregistered product as a tool to control pest is against the EU law. Basing on the definition of Regulation 1107/2009, all products that are applied to control pests, regardless of the composition, are plant protection products and must be registered as such.

\section{Conclusions}

The wide group of products discussed in this paper, namely micro-organisms, plant extracts, basic substances, as well as non-pesticidal products like biostimulants, biological yield enhancers, plant health promoters, and soil conditioners, have their place in the IPM strategies as presented in the Directive 128/2009.

However, unnecessary use of any preparations is not in line with the IPM principles. Before recommending the use of any products in agriculture, it is worth making sure that they are really needed, besides being safe and effective.

\section{Compliance with ethical standards}

Conflict of interest The author declares no conflict of interest.

Human and animal rights The article does not contain any human and animal rights.

Open Access This article is distributed under the terms of the Creative Commons Attribution 4.0 International License (http:// creativecommons.org/licenses/by/4.0/), which permits unrestricted use, distribution, and reproduction in any medium, provided you give appropriate credit to the original author(s) and the source, provide a link to the Creative Commons license, and indicate if changes were made.

\section{References}

Amorim L, de Barros RA, de Melo Diogo, Chalegre K, Fontes de Oliveira C, Regis L, Silva-Filha M (2010) Stability of Culex quinquefasciatus resistance to Bacillus sphaericus evaluated bymolecular tools. Insect Biochem Mol Biol 40:311-316

Bak K, Gaj R (2016) Effect of differentiated phosphorus and potassium fertilization on maize grain yield and plant nutritional status at a critical growth stage. J Elementol 21(2):337-348. https://doi.org/10.5601/jelem.2015.20.3.996

Bereś P (2016) Efficacy of spinosad and Bacillus thuringiensis var. Kurstaki in biological control of the European corn borer on sweet corn. Acta Sci Pol Hortorum Cultus 15(6):19-35

Boyer S, Zhang H, Lempérière G (2012) A review of control methods and resistance mechanisms in stored-product insects. Bull Entomol Res 102(2):213-229. https://doi.org/10.1017/ S0007485311000654

Crespo ALB, Rodrigo-Simon A, Siqueira HAA, Pereira EJG, Ferre J, Siegfried BD (2011) Cross-resistance and mechanism of resistance to $\mathrm{Cry} 1 \mathrm{Ab}$ toxin from Bacillus thuringiensis in a fieldderived strain of European corn borer, Ostrinia nubilalis. J Invertebr Pathol 107:185-192

Danilčenko H, Dabkevičius Z, Jarienė E, Tarasevičienė Ž, Televičiūtė D, Tamošiūnas A, Jeznach M (2017) The effect of stinging nettle and field horsetail extracts on the synthesis of biologically active compounds in germinated leguminous and quinoa seed. ZemdirbAgric 104(4):337-344. https://doi.org/10.13080/z-a.2017.104.043

Deising HB (2018) Revisiting wishful thinking: the need of molecular tools to accurately assess the risks associated with microbial biocontrol agents. J Plant Dis Prot 125:131-132

Deising HB, Gase I, Kubo Y (2017) The unpredictable risk imposed by microbial secondary metabolites: how safe is biological control of plant diseases? J Plant Dis Prot 124:413-419. https:// doi.org/10.1007/s41348-017-0109-5

Directive 2009/128/EC of the European Parliament and of the Council of 21 October 2009 establishing a framework for Community action to achieve the sustainable use of pesticides. Off J Eur Union L 309. Accessed 3 Aug 2018

EPPO Gudeline PP 1/296 (1) (2017) Principles of efficacy evaluation for low-risk plant protection products. Bulletin OEPP/EPPO 47, 297-304 https://doi.org/10.1111/epp.12396

Feldmann F (2017): Efficacy and risks of „biorationals“ in organic and integrated pest management-acceptable? Book of abstracts of the 8th international symposium plant protection and plant health in Europe, Braunschweig, 13-14 December 2017. http:// plant-protection.net/fileadmin/Tagungen/PPPHE/2017/Docu ments/PPPHE2017_Report.pdf. Accessed 3 Aug 2018

Fungicides Sorted by Mode of Action (including FRAC Code Numbering). [Online]. Fungicide Resistance Action Committee (2018). http://www.phi-base.org/images/fracCodeList.pdf. Accessed 8 June 2018

Ghorbanpour M, Omidvari M, Abbaszadeh-Dahaji P, Omidvar R, Kariman K (2018) Mechanisms underlying the protective effects of beneficial fungi against plant diseases. Biol Control 117:147-157. https://doi.org/10.1016/j.biocontrol.2017.11.006

IRAC MoA Classification Scheme, Version 8.4. [Online]. Insecticide Resistance Action Committee (2018). http://www.irac-online. org/documents/moa-classification/. Accessed 8 June 2018 
Kazda J, Herda G, Spitzer T, Řičařová V, Przybysz A, Gawrońska H (2015) J Pest Sci 88:235. https://doi.org/10.1007/s10340-0140603-5

Koch E, Becker O, Berg G, Hauschild R, Jehle J, Köhl J, Smalla K (2018) Biocontrol of plant diseases is not an unsafe technology! J Plant Dis Prot 125:121-125

Kocira S, Szparaga A, Kocira A, Czerwińska E, Wójtowicz A, Bronowicka-Mielniczuk U, Koszel M, Findura P (2018) Modeling biometric traits, yield and nutritional and antioxidant properties of seeds of three soybean cultivars through the application of biostimulant containing seaweed and amino acids. Front Plant Sci. https://doi.org/10.3389/fpls.2018.00388

Matyjaszczyk E (2015a) Products containing microorganisms as a tool in integrated pest management and the rules of their market placement in the European Union. Pest Manag Sci 71(9):1201-1206. https://doi.org/10.1002/ps.03986

Matyjaszczyk E (2015b) The introduction of biostimulants on the Polish market The present situation and legal requirements. Przem Chem 10:1841-1844. https://doi.org/10.15199/62.2015. 10.40

Matyjaszczyk E (2017) Comparison between seed and foliar treatment as a tool in integrated pest management. J Agric Food Chem 65(30):6081-6086. https://doi.org/10.1021/acs.jafc. $7 \mathrm{~b} 01095$

Matyjaszczyk E (2018) Plant protection means used in organic farming throughout the European Union. Pest Manag Sci 74:505-510. https://doi.org/10.1002/ps.4789
OECD Working Document on the Evaluation of Microbials for Pest Control ENV/JM/MONO(2008)36. [Online]. Organisation for Economic Co-operation and Development, Paris, France (2008). http://www.oecd.org/env/ehs/pesticides-biocides/41946259.pdf. Accessed 27 June 2018

Przybysz A, Gawrońska H, Gajc-Wolska J (2014) Biological mode of action of anitrophenolates-based biostimulant: case study. Front Plant Sci 5:713. https://doi.org/10.3389/fpls.2014.00713

Regulation (EC) No 1107/2009 of the European Parliament and of the Council of 21 October 2009 concerning the placing of plant protection products on the market and repealing Council Directives 79/117/EEC and 91/414/EEC Off J Eur Union L 309. Accessed 3 Aug 2018

Traon D, Amat L, Zotz F, du Jardin P (2014) A legal framework for plant biostimulants and agronomic fertilizer additives in the EU, Report for the European Commission Enterprise \& Industry Directorate-General, Arcadia International

Tratwal A, Bocianowski J (2018) Cultivar mixtures as part of integrated protection of spring barley. J Plant Dis Prot 125:41-50. https://doi.org/10.1007/s41348-017-0139-z

Yakhin OI, Lubyanov AA, Yakhin IA, Brown PH (2017) Biostimulants in plant science: a global perspective. Front Plant Sci 7:2049. https://doi.org/10.3389/fpls.2016.02049

Zitko SE, Timmer LW, Sandler HA (1991) Isolation of Phytophthora palmivora pathogenic to citrus in Florida. J Plant Dis 75:532-535 